\title{
IDENTIFICATION OF MOLECULAR BACTERIAL ISOLATE ENDOFIT BACTERIA KASTURI MANGO (Mangifera casturi Kosterm) LEAVES AND ANALYSIS OF ANTIBACTERIAL ACTIVITY
}

\author{
Usep Suhendar $^{1)^{*}}$, Siti Mahyuni ${ }^{1)}$, Sogandi $^{2)}$ \\ ${ }^{1)}$ Program Studi Farmasi, Universitas Pakuan, Bogor, 16143, Indonesia \\ ${ }^{2)}$ Fakultas Farmasi, Universitas 17 Agustus 1945, Jakarta, 14350, Indonesia
}

\section{ARTICLE INFO}

Article history:

Received 30 Jan 2021,

Accepted 17 Mar 2021

Available online 29 Apr 2021

Keywords:

$\checkmark$ Endophyte

$\checkmark$ Kasturi Mango

$\checkmark$ Antibacterial

*corresponding author: usep.suhendar@unpak.ac.id Phone: +62

https://doi.org/10.31938/jsn.v $\underline{11 \mathrm{i} 1.294}$

\begin{abstract}
The increase in infectious diseases caused by pathogenic bacteria impacts the increase in the incidence of pathogenic bacteria to antibiotics. This study aimed to find candidates for the endophytic bacterial isolates of kasturi mango, which have antibacterial potential. After being tested against the pathogenic bacteria, Bacterial isolates showed potential activity using the disc diffusion method. The observations of five endophytic bacterial isolates from the leaves of Kasturi mango, namely L1, L2, L3, L4, and L5, showed that L2 was the most potential compared to other isolates. The formation of a clear zone indicates the inhibitory activity. Molecular identification was carried out by PCR amplification on the $16 S$ rRNA gene. Furthermore, the L2 isolate was identified as Enterobacter cloacae with a $99 \%$ sequence similarity. Subsequent tests on several bacteria, including S. mutans ATCC 31987, S. aureus ATCC 25323, E. coli ATCC 25922 and Shigella dysenteriae ATCC 13313. All isolates showed an inhibition zone in the five bacteria.
\end{abstract}

\section{ABSTRAK \\ Identifikasi molekuler isolat bakteri endofit daun mangga kasturi (Mangifera casturi Kosterm) dan analisis aktivitas antibakteri}

\begin{abstract}
Meningkatnya angka kejadian penyakit menular yang diakibatkan oleh bakteri patogen berdampak pada meningkatknya kemampuan resistensi bakteri patogen terhadap antibiotik. Penelitian ini bertujuan untuk mendapatkan kandidat isolat bakteri endofit daun mangga kasturi yang memiliki aktivitas sebagai antibakteri. Isolat bakteri yang telah diujikan terhadap bakteri patogen Propionibacterium acnes menunjukkan aktivitas potensial dengan menggunakan metode difusi cakram. Hasil pengamatan dari lima isolat bakteri endofit dari daun mangga kasturi yaitu L1, L2, L3, L4, dan L5 menunjukan L2 yang paling potensial dibandingkan isolat yang lain. Aktivitas penghambatan ditunjukkan dengan terbentuknya zona bening. Identifikasi molekuler dilakukan dengan amplifikasi PCR pada gen 16S rRNA. Selanjutnya, isolat L2 diidentifikasi sebagai Enterobacter cloacae dengan kemiripan urutan 99\%. Pengujian berikutnya dilakukan terhadap beberapa bakteri diantaranya bakteri S. mutans ATCC 31987, S. aureus ATCC 25323, E. coli ATCC 25922 dan S. dysenteriae ATCC 13313. Semua isolat menujukkan adanya zona hambat pada kelima bakteri tersebut.
\end{abstract}

Kata Kunci: Endofit; Mangga Kasturi, Antibakteri

\section{PENDAHULUAN}

Meningkatnya kasus penyakit menular yang diakibatkan oleh bakteri patogen memiliki dampak pada bertambahnya jumlah bakteri yang memiliki kemampuan pertahanan terhadap antibiotik, bakteri tersebut diantaranya adalah $S$. aureus dan
P. aeruginosa (Nascimento et al., 2000). Solusi alternatif diperlukan untuk dapat menemukan sumber antibiotik baru yaitu dengan melakukan eksplorasi tanaman yang berpotensi sebagai tanaman obat. Tanaman yang banyak dieksplorasi sebagai tanaman obat adalah tanaman mangga kasturi. Tanaman mangga kasturi (Mangifera 
casturi Kosterm) merupakan tanaman endemik dari Kalimantan Selatan. Tanaman ini dilaporkan mengandung senyawa santon, saponin, flavonoid, terpenoid, dan fenolik (Sutomo dkk., 2014). Beberapa senyawa tersebut diketahui memiliki aktivitas senyawa metabolit yang dapat dimanfaatkan sebagai obat.

Ada beberapa kendala dalam menguji senyawa bioaktif dari sumber tanaman, salah satunya adalah diperlukan jumlah sampel yang banyak didalam pengujiannya. Solusi alternatif untuk dapat mengatasi kendala tersebut, yaitu dengan pemanfaatan bakteri endofit yang bersimbiosis di dalam jaringan tanaman. Salah satu sifat dari bakteri endofit adalah tidak memiliki dampak negatif terhadap tanaman. Bakteri endofit dan tanaman diketahui menunjukkan hubungan simbiosis mutualisme (Strobel \& Daisy, 2003; Radji, 2005). Sehingga, beberapa laporan menyatakan bahwa senyawa metabolit yang diproduksi oleh bakteri endofit adalah sesuai dengan tumbuhan inangnya. Oleh karena itu, hal tersebut menjadi peluang yang sangat besar untuk dapat memproduksi senyawa metabolit yang dapat dijadikan sebagai alternatif dalam pengobatan (Oktafia, 2009).

Pada umumnya, tumbuhan mengandung beberapa bakteri endofit yang mampu memproduksi senyawa metabolit dengan karakteristik sama dengan senyawa metabolit yang dihasilkan oleh tanaman inangnya (Prasetyoputri $\&$ Ines, 2006). Senyawa metabolit tersebut dapat diproduksi oleh bakteri endofit dan berpotensi untuk dapat dikembangkan pada berbagai bidang (Elena et al., 2016; Castillo et al.,2003). Bakteri endofit diketahui memiliki kemudahan dalam pengambilan senyawa metabolitnya. Kemampuan bakteri endofit untuk menghasilkan senyawa metabolit yang sesuai dengan tanaman inangnya merupakan potensi yang sangat besar dan dapat diandalkan untuk menghasilkan senyawa metabolit (Zhang et al., 1999). Berbagai penelitian mengenai bakteri endofit telah dilaporkan, diantaranya adalah menghasilkan antibiotik dengan spektrum luas yaitu bakteri endofit yang diisolasi dari Grevillea pteridifolia. Endofit tersebut menghasilkan kakadumycin yang berkhasiat sebagai agen anti-malaria (Ryan et al., 2008). Bakteri endofit Pestalotiopsis microspora yang diisolasi dari tanaman Taxus dapat menghasilkan paclitaxel yang berkhasiat sebagai antikanker
(Premkumar \& Govindrajan, 2005). Bakteri endofit Pseudomassaria sp. menghasilkan metabolit sekunder yang memiliki mekanisme kerja seperti insulin dan telah terbukti mengurangi kadar glukosa darah yang diujikan pada tikus (Rahmadani, 2014).

Pada penelitian sebelumnya yang telah dilakukan, didapatkan lima isolat yang diperoleh dari bagian daun mangga kasturi, yaitu L1, L2, L3, L4, dan L5. Isolat yang potensial setelah diujikan terhadap bakteri Propionicbacterium acnes, yaitu isolat L2 yang memiliki aktivitas antibakteri lebih baik dibandingkan bakteri endofit lainnya. Penelitian saat ini merupakan penelitian lanjutan yang bertujuan untuk melakukan pengambilan bakteri endofit dengan memisahkannya dari daun mangga kasturi, melakukan identifikasi terhadap bakteri endofit dari daun mangga kasturi, dan mengetahui aktivitas antibakterinya.

\section{BAHAN DAN METODE}

\section{Bahan dan Alat}

Penelitian ini dilakukan di Laboratorium Farmasi Universitas Pakuan, Laboratorium Farmasi, Universitas 17 Agustus 1945, dan Laboratorium Mikrobiologi IPB University. Penelitian ini telah dilaksanakan pada bulan Juli hingga Oktober 2020.

Bahan-bahan yang digunakan dalam penelitian ini adalah isolat L2 yang merupakan isolat yang diambil dari bagian daun mangga kasturi, media Nutrient Broth (NB), buffer TE (10 $\mathrm{mM}$ Tris-HCl pH 8.0, $1 \mathrm{mM}$ EDTA), buffer TBE (10 mM Tris-Borate-EDTA (TBE) Buffer, pH 8.3), SDS 10\%, CTAB 10\%, Primer 27F (5 AGA GTT TGA TCM TGG CTC AG 3') dan 1492R (5 GGT TACCTT GTT ACG ACT T 3`), bakteri S. mutans ATCC 31987, S. aureus ATCC 25323, E. coli ATCC 25922 dan S. dysenteriae ATCC 13313. Alat-alat yang digunakan dalam penelitian ini adalah Polymerase Chain Reaction (PCR), peralatan gelas, tabung sentrifugasi, dan peralatan pendukung lainnya.

\section{Metode}

\section{Penyiapan Kultur Bakteri Endofit}

Sebanyak $10 \mu \mathrm{L}$ isolat $\mathrm{L} 2$ dipindahkan ke dalam tabung reaksi berisi $5 \mathrm{~mL}$ media NB. Isolat kemudian diinkubasi dengan waktu minimal 18 
jam pada suhu $37^{\circ} \mathrm{C}$. Kultur dimasukkan ke dalam tabung sentrifugasi, kemudian disentrifugasi pada kecepatan $10.000 \mathrm{~g}$ selama 10 menit. Selanjutnya supernatan diukur aktivitas antibakterinya.

\section{Isolasi Genom}

DNA genom dari bakteri endofit diisolasi dalam skala kecil dengan mengikuti Zhu et al. (1993) dan Ziniel et al. (2002) yang dimodifikasi. Sebanyak $5 \mathrm{~mL}$ kultur ditumbuhkan di media NB pada suhu $37{ }^{\circ} \mathrm{C}$. Lalu, kultur tersebut disentrifugasi pada $10.000 \mathrm{~g}$ selama 10 menit. Pelet yang terbentuk dilakukan resuspensi dengan $500 \mu \mathrm{L}$ buffer TE $(10 \mathrm{mM}$ Tris-HCl pH 8,0, $1 \mathrm{mM}$ EDTA) yang mengandung $60 \mathrm{mg} / \mathrm{mL}$ lisozim dan kemudian diinkubasi pada $37^{\circ} \mathrm{C}$ selama 60 menit. Larutan ditambahkan $200 \mu \mathrm{L}$ SDS $10 \%, 100 \mu \mathrm{L}$ $5 \mathrm{M}$ natrium klorida dan $80 \mu \mathrm{L}$ CTAB $10 \%$. Campuran kemudian diinkubasi pada suhu $68^{\circ} \mathrm{C}$ selama 30 menit, ditambahkan kloroform dengan perbandingan volume $1: 1(\mathrm{v} / \mathrm{v})$. Lalu, campuran tersebut disentrifugasi dengan $10.000 \mathrm{~g}$ selama 10 menit. Supernatan ditambahkan larutan etanol dengan perbandingan volume 1:1 (v/v) kemudian dilakukan sentrifugasi. Supernatan dibuang secara perlahan agar pelet tidak ikut terbuang. Pelet yang mengandung DNA dilarutkan dalam $30 \mu \mathrm{L}$ buffer

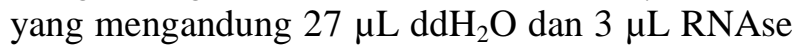
dan disimpan dalam $-20{ }^{\circ} \mathrm{C}$.

\section{Elektroforesis Genom dengan Gel}

Sebanyak $3 \mu \mathrm{L}$ DNA genom dicampur dengan $2 \mu \mathrm{L}$ loading dye, kemudian dimigrasikan di gel 0,8\% agarosa di dalam buffer TBE. Buffer TBE mengandung 1xTris-Borate-EDTA (TBE) Buffer dengan $\mathrm{pH}$ 8,3. Selanjutnya, dilakukan elektroforesis pada $100 \mathrm{~V}$ selama 30 menit. Gel agarosa direndam di larutan EtBr selama 15 menit, kemudian direndam di $\mathrm{H}_{2} \mathrm{O}$ selama 5 menit. Pita DNA genom selanjutnya divisualisasi dengan menggunakan pencahayaan sinar UV.

\section{Amplifikasi gen penyandi 16S rRNA}

Amplifikasi DNA dilakukan menggunakan mesin PCR dengan menggunakan primer 27F (5 AGA GTT TGA TCM TGG CTC AG 3') dan 1492R (5` GGT TACCTT GTT ACG ACT T 3’). Reaksi PCR terdiri dari $1 \mu \mathrm{L}$ DNA cetakan dengan volume $25 \mu \mathrm{L}$. Amplifikasi dilakukan sebanyak 35 siklus dengan kondisi pra-PCR pada $94^{\circ} \mathrm{C}$, diikuti dengan denaturasi awal $94^{\circ} \mathrm{C}$ selama 15 detik, annealing $52^{\circ} \mathrm{C}$ selama 30 detik dan elongasi pada suhu $72^{\circ} \mathrm{C}$ selama 45 detik dan pasca-PCR $72^{\circ} \mathrm{C}$ selama 15 menit.

\section{Isolasi gen}

Isolasi gen penyandi $16 \mathrm{~S}$ rRNA dari gel dilakukan dengan menggunakan kit dari Zymoresearch. Gel yang mengandung pita DNA yang spesifik dipotong dan ditimbang. Gel dilarutkan dengan 3 kali volume buffer Agarose Dissolving Buffer (ADB) pada suhu $55^{\circ} \mathrm{C}$ selama 10 menit. Sampel dipipet kemudian diletakkan ke dalam kolom untuk selanjutnya dilakukan sentrifugasi dengan kecepatan 10.000 g selama 1 menit kemudian supernatan dibuang. Sebanyak $200 \mu \mathrm{L}$ wash buffer ditambahkan kemudian dilakukan sentrifugasi kembali pada $10.000 \mathrm{~g}$ selama 1 menit. Supernatan dibuang dan kolom ditambah dengan $200 \mu \mathrm{L}$ wash buffer kemudian disentrifugasi pada kecepatan $10.000 \mathrm{~g}$ selama 1 menit. Kolom dipindahkan ke tabung baru sebagai tempat penampung. Kolom kemudian ditambahkan dengan $20 \mu \mathrm{L}$ ddH2O, diinkubasi pada suhu $25^{\circ} \mathrm{C}$ selama 2 menit kemudian selanjutnya dilakukan sentrifugasi pada kecepatan $10.000 \mathrm{~g}$ selama 2 menit. Cairan digunakan untuk analisis urutan nukleotida.

\section{Pengurutan nukleotida dan analisis kemiripan nukleotida}

Urutan DNA dalam bentuk format ab1 diolah dengan program DNA MAN. Kemudian, hasil tersebut disimpan dalam format fasta dan dianalisis kesejajaran dengan tools BLASTN NCBI yang selanjutnya dilakukan rekonstruksi filogenetik. Filogenetik ini berfungsi untuk mengetahui hubungan kekerabatan isolat bakteri endofit potensial dengan spesies lain menggunakan software MEGA v7.0.

\section{Pengukuran Aktivitas Antibakteri (Nascimento et al., 2000 dengan modifikasi)}

Pengukuran aktivitas antibakteri secara kualitatif dilakukan berdasarkan metode difusi agar. Bakteri uji yang digunakan adalah $S$. mutans ATCC 31987, S. aureus ATCC 25323, E. coli ATCC 25922 dan S. dysenteriae ATCC 13313. Sebanyak $25 \mu \mathrm{L}$ supernatan hasil kultur dari bakteri endofit diteteskan kedalam sumur (diameter $6 \mathrm{~mm}$ ) pada media NB yang telah mengandung $10^{8} \mathrm{CFU} / \mathrm{mL}$ bakteri uji di dalam 
cawan petri. Bakteri uji yang digunakan merupakan kultur yang telah ditumbuhkan pada media NB selama satu malam. Cawan petri diinkubasi pada suhu $37{ }^{\circ} \mathrm{C}$ selama 24 jam. Aktivitas inhibisi diamati dengan adanya zona bening dan diameter dari zona bening diukur. Zona bening yang terbentuk di sekitar area sumur menandakan bahwa metabolit sekunder bakteri endofit mangga kasturi mampu menghambat pertumbuhan bakteri endofit. Isolat bakteri endofit yang positif menunjukkan zona hambat terhadap semua patogen dan dikatakan sebagai isolat potensial.

\section{HASIL DAN PEMBAHASAN}

\section{Identifikasi Molekuler}

Isolat yang diperoleh merupakan isolat bakteri endofit yang diperoleh dari penelitian sebelumnya. DNA genom diamplifikasi dengan menggunakan gen 16S rRNA. Hasil PCR di elektroforesis dengan mengaplikasikan gel agarosa $0,8 \%$ pada 100 volt selama 60 menit dan gel agarosa divisualisasikan di bawah sinar UV. Amplifikasi gen penyandi $16 \mathrm{~S}$ rRNA menghasilkan pita DNA berukuran sekitar $1500 \mathrm{pb}$ (Gambar 1). Hasil pengurutan DNA menunjukkan bahwa hasil amplifikasi 16S rRNA dari isolat L2 mempunyai ukuran $1370 \mathrm{pb}$, dan urutan nukleotidanya disajikan pada Gambar 2. Analisis kesejajaran berdasarkan sebagian gen penyandi $16 \mathrm{~S}$ rRNA dari isolat L2 dengan BLAST di NCBI-GenBank menunjukkan bahwa isolat L2 memiliki kemiripan 100\% dengan Enterobacter strain ACP6 (nomor aksesi: MH915674.1).

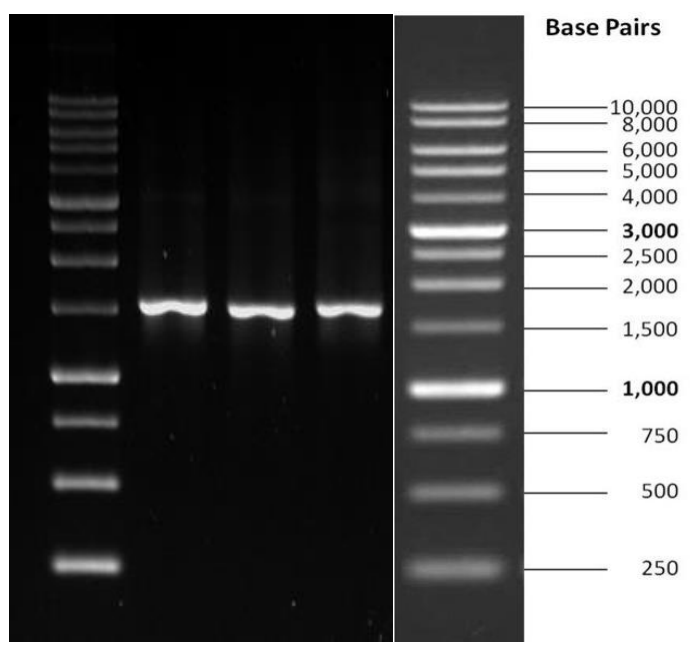

Gambar 1. Elektroforesis hasil PCR gen penyandi16S rRNA dari isolat $\mathrm{L} 2$

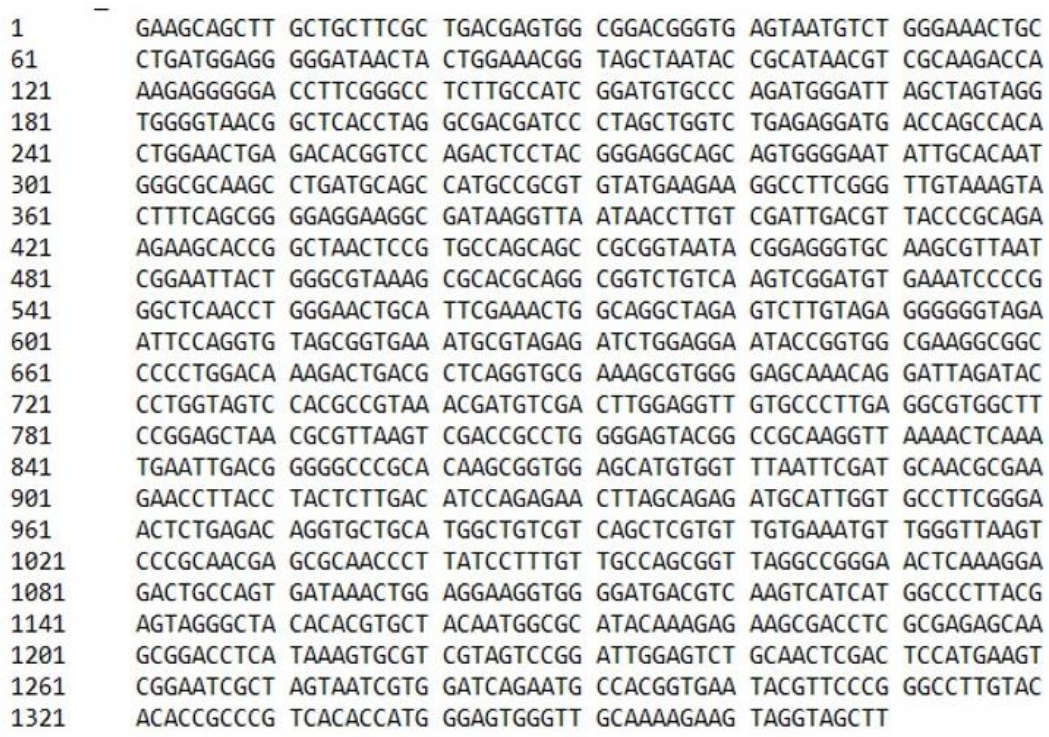

Gambar 2. Urutan nukleotida hasil amplifikasi 16S RNA 


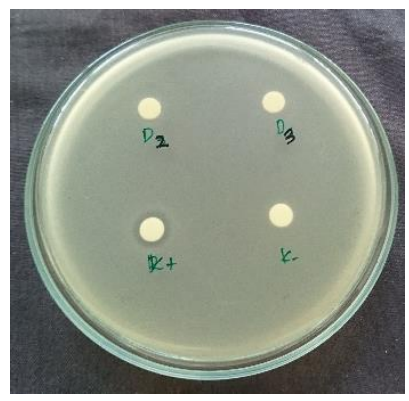

(a)

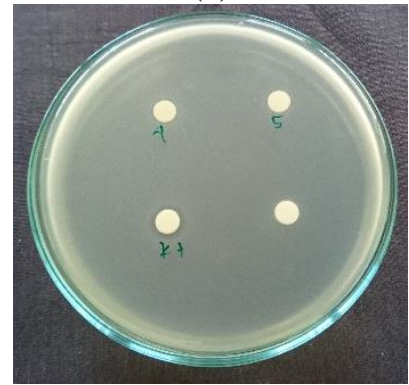

(c)

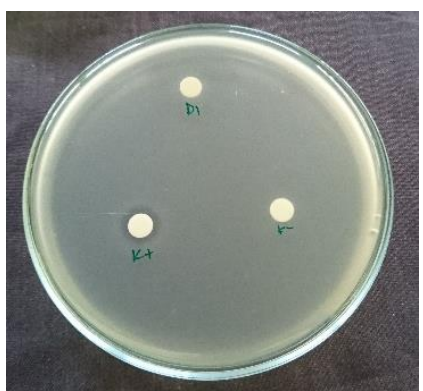

(b)

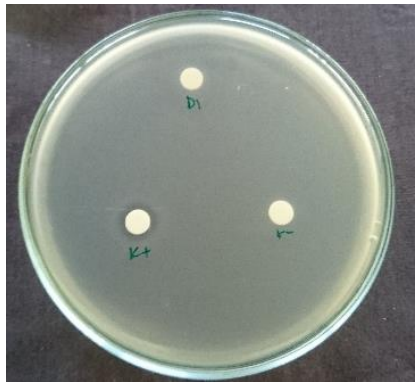

(d)

Gambar 3. Hasil uji aktivitas isolat L2 terhadap beberapa bakteri; a) Escherichia coli, b) Salmonella typhi, c) Staphylococcus aureus, dan d) Pseudomonas aeruginosa.

Penjajaran urutan bakteri diambil dari database GenBank, dilakukan di Clustal X2. Selanjutnya, hasil alignment dimasukkan ke dalam NJPlot untuk membuat pohon filogenetik. Gen penyandi $16 \mathrm{~S}$ rRNA yang digunakan pada hasil aligment pada pohon filogenetik menunjukkan bahwa isolat L2 termasuk dalam famili Enterobacteriaceae dan termasuk ke dalam klade Enterobacter. Enterobacter dilaporkan adalah jenis bakteri gram negatif. Adapun karakteristik Enterobcater yaitu memiliki fluktuasi anaerob, berbentuk batang, dan motil. Enterobacter sp. dilaporkan merupakan bakteri yang dapat menghasilkan beberapa enzim, diantaranya enzim protease, amilase, dan selulase. Secara umum, protease digunakan sebagai probiotik yang baik bagi manusia maupun hewan, karena dapat menekan pertumbuhan bakteri patogen yang hidup bersimbiosis pada manusia dan hewan. Enterobacter sp. telah dilaporkan sebagai jamur endofit dan terkait pada tanaman, seperti lidah buaya. Ekstrak kasar dan fraksi etil asetat dari metabolit lidah buaya mempunyai aktivitas antimikroba, yaitu terhadap bakteri patogen $P$. aeruginosa, S. aureus, B. cereus, S. Typhimurium, $P$. vulgaris, K. pneumonia, E. coli, S. pyogenes.

\section{Aktivitas Antibakteri dari Bakteri Endofit Daun Mangga Kasturi}

Pengujian aktivitas isolat L2 terhadap bakteri lain menunjukkan bahwa L2 dapat menghambat pertumbuhan E. coli, S. typhi, S. aureus, dan $P$. aeruginosa, walaupun aktivitasnya masih sangat rendah (Gambar 3). Hasil ini sesuai dengan penelitian yang dilakukan terhadap bakteri endofit dari Mangifera indica yang menunjukkan aktivitas antibakteri terhadap E. coli, S. typhi, S. aureus, dan $P$. aeruginosa, serta menghasilkan senyawa yang secara khusus bertanggung jawab terhadap sifat antimikroba, yaitu mangiferin dan asam galat (Sikine et al., 2017).

\section{KESIMPULAN}

\section{Kesimpulan}

Berdasarkan gen penyandi $16 \mathrm{~S}$ rRNA, isolat L2 yang merupakan bakteri endofit dari Mangifera casturi adalah Enterobacter sp. Bakteri L2 ini mempunyai aktivitas anti bakteri patogen Escherichia coli, Salmonella typhi, Staphylococcus aureus, dan Pseudomonas aeruginosa. 


\section{UCAPAN TERIMA KASIH}

Terima kasih kepada Universitas Pakuan yang telah membiayai penelitian ini melalui skema penelitian dosen pemula tahun 2020 .

\section{DAFTAR PUSTAKA}

Castillo, U. .J., Harper, K., Strobel, G. A., Sears, J., Alesi, K., Ford, E., et al. (2003). Kakandumycins, novel antibiotic from Streptomyces sp. NRRL 30566, an endophytes of Grevillea pteridifolia. FEMS Lett. 24, 183-190.

Elena, Martinez-Klimova, Karol, R., Sergio, S. (2016). Endophytes as sources of antibiotics.Journal Biochemical Pharmacology.

Nascimento, G. G. F,. Locatelli, J., Paulo, C. F., and Giuiliana, L. S. (2000). Brazilian Journal of Microbiology, 31, 247.

Oktafia, S. (2009). Uji Aktifitas Antibakteri Ekstrak Metanol Kulit batang Kasturi (Mangifera casturi Kosterm) Terhadap Bakteri Vibrio cholera dan Escherichia coli secara In Vitro. (Skripsi). Universitas Lambung Mangkurat, Banjarbaru.

Prasetyoputri, A., Ines, A. (2006). Mikroba endofit sumber acuan baru yang berpotensi. Biotrend. 1(2), 13-15.

Premkumar, T. and Govindrajan. (2005). Antimicrobial study of pyrazine, pyrazole and imidazole carboxylic acids and their hydrazinium salts. World Journal of Microbiology \& Biotechnology, 21, 479 480.

Radji, M. (2005). Peranan Bioteknologi dan Mikroba Endofit dalam Pengembangan Obat Herbal. Majalah Ilmu Kefarmasian. 3, 113126.
Rahmadani, A. (2014). Isolasi dan uji aktivitas antibakteri metabolit sekunder daun tendani (Goniothalamus macrophyllus Hook.f. \& Thoms). (Tesis). Universitas Gajah Mada.Yogyakarta.

Ryan, R. P., Germaine, K., Franks, A., Ryan, D. J., Dowling, D. N. (2008). Minireview: Bacterial endophytes: recent development and application. FEMS Microbiol Lett, 278: $1-9$.

Sikine, M., Kandri Rodi, Misbahi, Chraibi, M., Kandri Rodi A., Ouzanni C, Fikri B, Essassi M. (2017). Antibacterial Activity of New Pyrido[2,3-B]Pyrazine Derivatives. J. Mar. Chim. Hetercycl, 16(1).

Sutomo, S. Wahyuono, E.P., Setyowati, S. Rianto \& A. Yuswanto. (2014). Antioxidant activity assay of extracts and active fractions of kasturi fruit (Mangifera casturi Kosterm.) using 1, 1-diphenyl-2- picrylhydrazyl method. Journal of Natural Products. 7, 124-130.

Strobel, G. A., and Daisy. (2003). Bioprospecting for Microbial Endophytess and Their Natural Product. Microbiology and Moleculer Biology Review, 67, 491-502.

Zhang, B., Salituro, G., Szalkowski, D., Li, Z., Zhang, Y., Royo, I., et al. (1999). Discovery of small molecule insulin mimetic with antidiabetic activity in mice. Science, 284, 974-981.

Zhu, H., Qu, F., Zhu, L. H. (1993). Isolation of genomic DNAs from plants, fungi and bacteria using benzyl chloride. Nucl Acids Res, 21, 5279-5280.

Zinniel, D. K, Lambrecht, P., Harris, B. N, Feng, Z., Kuczmarski, D., Higley, P., et al. (2002). Isolation and characterization of endophytic colonizing bacteria from agronomic crops and prairie plants. Applied and Environmental Microbiology, 68(5), 21982208. 